\title{
PENERAPAN METODE STORYTIVITY UNTUK MENINGKATKAN KEMAMPUAN MENULISKAN KEMBALI CERITA ANAK PADA SISWA KELAS II-B SD AL MUTTAQIEN SURABAYA TAHUN PELAJARAN 2018-2019
}

\author{
ERLIN WIDIANA \\ SD Al Muttaqien Surabaya \\ e-mail.widiana9@gmail.com
}

\begin{abstract}
ABSTRAK
Tujuan penelitian penerapan metode storytivity ini adalah untuk meningkatkan kemampuan menuliskan kembali cerita anak dan meningkatkan kualitas proses pembelajaran menuliskan kembali cerita anak pada siswa kelas II-B SD Al Muttaqien Surabaya melalui penelitian tindakan kelas yang terdiri atas pratindakan, tindakan siklus I, dan tindakan siklus II. Data yang diambil dalam penelitian ini merupakan data observasi tindakan guru dan siswa pada siklus I dan II serta tes menuliskan kembali cerita anak setelah adanya tindakan penerapan storytivity. Dari hasil penelitian diperoleh data terjadi peningkatan pembelajaran menuliskan kembali cerita anak yang ditandai dengan meningkatnya keaktifan, motivasi, dan percaya diri siswa dalam pembelajaran pada setiap siklusnya. Kemampuan siswa dalam menuliskan kembali cerita anak menjadi lebih baik. Siswa telah mencapai kriteria ketuntasan minimal sebanyak $12 \%$ pada pratindakan, $50 \%$ pada siklus I, dan $90 \%$ pada siklus II. Dengan demikian dapat dikemukakan bahwa pembelajaran dengan penerapan metode storytivity mampu meningkatkan kualitas proses pembelajaran menuliskan kembali cerita anak dan meningkatkan kemampuan menuliskan kembali cerita anak pada siswa kelas II-B SD Al Muttaqien Surabaya semester ganjil tahun pelajaran 2018-2019.
\end{abstract}

Kata Kunci: Metode Storitivity, Menulis Cerita, Penelitian Tindakan Kelas

\section{PENDAHULUAN}

Keterampilan berbahasa yang diajarkan dalam mata pelajaran bahasa Indonesia terdiri dari empat aspek yaitu aspek mendengarkan, berbicara, membaca, dan menulis. Keempat aspek yang diajarkan tersebut berhubungan satu sama lain, jika seseorang mendengarkan pasti ada orang yang berbicara, begitu pula orang yang membaca berarti ia menikmati dan menghayati tulisan orang lain. Keempat keterampilan berbahasa sebagai alat untuk berkomunikasi harus dikuasai oleh setiap orang. Kegiatan berbahasa yang produktif adalah kegiatan menyampaikan gagasan, pikiran, atau perasaan oleh pihak penutur. Kegiatan berbahasa yang produktif terdiri dari dua macam yaitu berbicara dan menulis. Berbicara menggunakan sarana lisan sedangkan menulis menggunakan sarana tulisan. Aktivitas menulis merupakan salah satu manisfestasi keterampilan berbahasa paling akhir yang dikuasai pembelajar bahasa setelah mendengarkan, membaca, dan berbicara. (Nurgiyantoro, 2001)

Kegiatan menulis pada jenjang SD kelas II diwujudkan dengan kompetensi dasar berbunyi: menceritakan kembali cerita anak yang didengarkan menggunakan kata-kata sendiri. Menulis cerita merupakan salah satu kegiatan yang paling spektakuler, banyak manfaat yang dapat diperoleh dari menulis cerita, diantaranya melatih konsentrasi dan merangsang imajinasi anak. Cerita merupakan alat yang ampuh untuk menggali dan menyampaikan ilmu pengetahuan terutama oleh anak-anak. (Dewiyana, 2009)

Fenomena yang terjadi di kelas II-B SD Al Muttaqien Surabaya pada saat guru mengajar kompetensi dasar: menceritakan kembali cerita anak yang didengarkan menggunakan kata-kata sendiri, menunjukkan kualitas proses dan hasil pembelajaran yang rendah. Hasil studi awal penelitian proses pembelajaran menuliskan kembali cerita anak di kelas II-B SD Al Muttaqien Surabaya dengan jumlah siswa sebanyak 33 anak menunjukkan hanya terdapat $12 \%$ siswa yang telah mencapai kriteria ketuntasan minimal, yaitu 75. Sebagian besar siswa belum menguasai kemampuan menuliskan kembali cerita. 
Berdasarkan hasil pengamatan peneliti rendahnya keterampilan menulis siswa, khususnya menuliskan kembali cerita anak disebabkan oleh beberapa faktor diantaranya (1) guru kurang membiasakan siswa terhadap tradisi menulis sehingga menyebabkan siswa menjadi terbebani apabila mendapatkan tugas untuk menulis, (2) metode pembelajaran yang dilaksanakan oleh guru kurang tepat yaitu guru membacakan cerita, siswa menjawab pertanyaan berdasarkan cerita kemudian siswa menuliskan kembali cerita tersebut dengan menggunakan kata-kata sendiri, (3) media pembelajaran yang variatif tidak dimunculkan oleh guru, (4) siswa belum mampu dalam menuangkan ide/gagasan dengan baik serta sebagian siswa membutuhkan waktu yang cukup lama untuk dapat menuangkan ide dan gagasannya, (5) siswa kurang bisa mengembangkan bahasa.

Melihat kondisi demikian, peneliti selaku guru tematik di kelas II-B beserta pendidik mitra berusaha untuk memberikan solusi alternatif dalam pembelajaran menuliskan kembali cerita anak agar segala permasalahan serta kendala yang terdapat pada siswa maupun guru dapat teratasi yaitu penggunaan metode storytivity.

Metode storytivity adalah metode yang memuat story (cerita) dan activity (aktivitas), mengembangkan aspek visual, auditori, dan kinestetik di dalamnya terdapat unsur storytelling (bercerita), gambar, warna, tokoh, bermain peran, dan pesan-pesan moral serta menggunakan kartu bergambar sebagai media untuk bercerita dan boneka kertas yang dapat dirangkai sendiri oleh siswa sebagai alat peraga bercerita. Metode storytivity merupakan metode yang mengembangkan imajinasi dan kreativitas anak. Teks cerita yang diperdengarkan kepada siswa sebagai sarana bagi siswa untuk menceritakan ulang. Lewat kartu bergambar, siswa dapat mengembangkan imajinasi berdasarkan cerita yang sudah didengarnya. Siswa bebas untuk mengembangkan cerita sesuai dengan imajinasinya dan semua yang telah diingatnya. Dengan demikian, daya imajinasi dan kemampuan bahasanya terus berkembang. Harapannya, siswa menjadi lebih kreatif. (Wijaya, 2009)

Boneka kertas sebagai alat peraga bercerita akan membuat anak lebih bersemangat. Mereka belajar memainkan peran dan guru bisa memasukkan nilai-nilai moral yang penting bagi pengembangan perilaku siswa. Aktivitas dalam merangkai boneka kertas seperti menggunting, melipat, dan merekatkan akan semakin mengembangkan motorik anak. Selain itu siswa juga diajarkan untuk teliti, tekun, dan rapi. (Wijaya, 2009) Diharapkan dengan metode storytivity masalah kesulitan siswa kelas II-B dalam menuliskan kembali cerita anak akan dapat terselesaikan.

Berdasarkan uraian di atas penulis terdorong untuk melakukan penelitian tindakan kelas dengan judul "Penerapan Metode Storytivity untuk Meningkatkan Kemampuan Menuliskan Kembali Cerita Anak pada Siswa Kelas II-B SD Al Muttaqien Surabaya Tahun Pelajaran 20182019."

\section{METODE PENELITIAN}

Prosedur penelitian yang digunakan dalam penelitian ini adalah penelitian tindakan kelas. Rancangan yang digunakan adalah model rancangan yang dikembangkan oleh Stephen Kemmis dan Mc. Taggart (dalam Arikunto, 2006) dengan menggunakan dua siklus, masingmasing siklus terdiri dari empat tahap yakni: 1) Merencanakan (plan), 2) Melakukan Tindakan (act), 3) Mengamati (observe), 4) Refleksi (reflect). 
Berikut ini adalah gambar rancangan penelitian tindakan kelas menurut Stephen Kemmis dan Mc. Taggart.

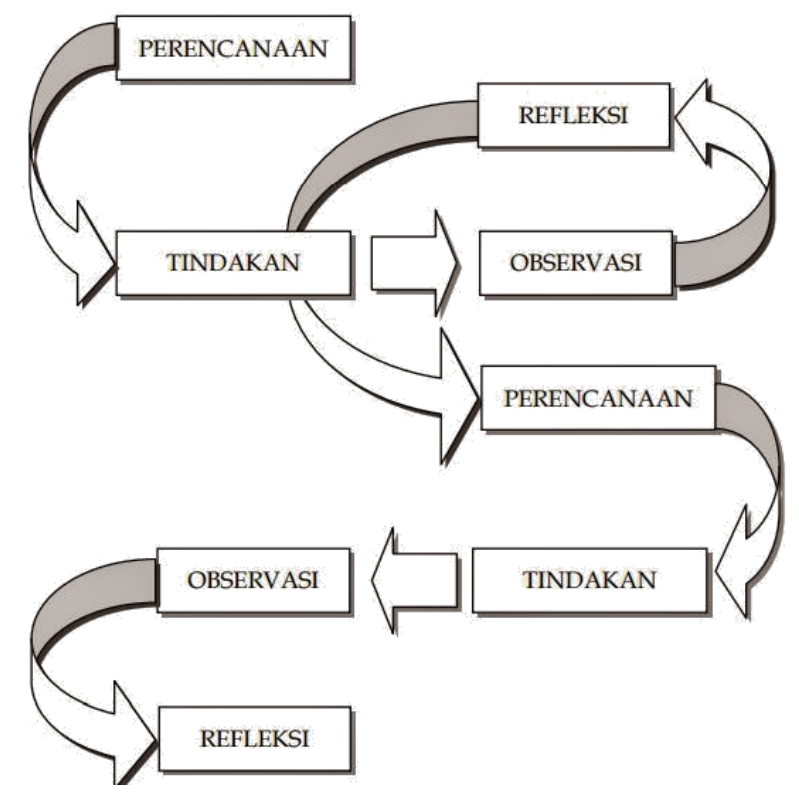

Gambar 1. Tahapan dalam siklus Penelitian Tindakan Kelas Model Kemmis \& Taggart.

Sumber: Arikunto, 2007

Penelitian ini dilakukan dengan tindakan yang dilaksanakan dengan langkah-langkah penelitian yang telah direncanakan, yaitu dengan terlebih dahulu menyusun RPP yang berisi langkah-langkah dalam pelaksanaan pembelajaran. Langkah selanjutnya adalah pengumpulan data yang dilaksanakan dengan melakukan observasi, Setelah data diperoleh kemudian dilakukan refleksi dan melakukan laporan hasil penelitian. Tindakan siklus I dilaksanakan pada pekan ke-3 Oktober 2018 sedangkan tindakan siklus II dilaksanakan pada pekan ke-4 Oktober 2018.

Data yang diperoleh dari penelitian ini berupa data awal yang didapatkan dari data pratindakan, data yang diperoleh pada saat tindakan dan data hasil tindakan. Peneliti memperoleh data awal tindakan dari hasil observasi di kelas sebelum ada tindakan. Dari data awal didapatkan informasi bahwa peserta didik memerlukan tindakan untuk memecahkan permasalahan rendahnya kemampuan menuliskan kembali cerita anak.

Data inti diperoleh selama tindakan. Dari hasil tindakan diperoleh data verbal yaitu data yang diperoleh peneliti selama observasi. Dalam data ini peneliti mencatat aktifitas peserta didik dan juga aktifitas yang dilakukan guru selama tindakan berlangsung. Data ini selanjutnya dikategorikan data aktifitas peserta didik dan data aktifitas guru. Selain data verbal, peneliti memproleh data non verbal yang didapatkan dari hasil postes sesudah tindakan siklus I dan siklus II. Dari tampilan data baik verbal maupun non verbal, peneliti memperoleh hasil refleksi yang didukung oleh guru dan teman sejawat yaitu berupa kelemahan-kelemahan serta hambatan yang ditemukan yang selanjutkan dipakai sebagai dasar perbaikan pada siklus berikutnya.

\section{HASIL DAN PEMBAHASAN}

\section{HASIL}

\section{A. Pelaksanaan Tindakan dan Hasil Penelitian}

\section{Siklus I}

\section{a. Hasil Belajar}

Setelah dilakukan siklus I diperoleh data rata-rata jumlah kata seluruh siswa kelas II-B dalam menuliskan kembali cerita anak setelah siklus I adalah 74 kata, siswa masih kesulitan mencari kata-kata dan kalimat yang tepat untuk menulis, jumlah kata terendah yang dihasilkan siswa adalah 28 kata, sedangkan jumlah kata tertinggi yang 
dihasilkan siswa adalah 95 kata, terdapat peningkatan kemampuan siswa dalam menuliskan kembali cerita anak, masih terdapat 50\% siswa yang belum mencapai KKM dalam menulis cerita, siswa masih kesulitan menggali ide dan kata dalam tulisan mereka.

\section{b. Pengamatan (Observasi)}

\section{- Pelaksanaan Tindakan Guru}

Tindakan siklus I dilaksanakan sesuai dengan menjalankan RPP yang telah disusun dalam tiga pertemuan (6 x 30 menit). Guru membuka pelajaran dan memberikan apersepsi mengenai pengalaman siswa dibacakan cerita oleh orang tua, cerita yang pernah mereka dengar, apakah mereka menyukai cerita tersebut lalu guru membentuk kelompok baru untuk siswa beranggotakan 4 anak lalu mengkondisikan siswa untuk tenang dan diam saat akan dimulai pembacaan cerita. Guru membacakan teks cerita "Hansel \& Gretel" dengan cara yang interaktif, namun tidak mempersilahkan siswa untuk bertanya tentang cerita yang telah dibacakan. Guru membagikan beberapa kartu bergambar pada masing-masing kelompok, memberi instruksi yang jelas kepada siswa tentang kegiatan mengurutkan kartu bergambar, membimbing siswa dalam kelompok untuk mengurutkan kartu bergambar dengan cara memberikan nomor urut pada kotak yang telah disediakan di pojok kiri atas kartu bergambar, memberikan penguatan pada beberapa kelompok yang berhasil mengurutkan kartu bergambar, namun tidak semua kelompok mendapat penguatan. Guru meminta siswa berdiskusi menentukan juru bicara untuk masing-masimg kelompok, memberikan contoh bagaimana cara menceritakan kisah "Hansel \& Gretel" secara lisan di depan kelas menggunakaan kartu bergambar, meminta siswa menceritakan secara lisan cerita "Hansel \& Gretel" berdasarkan kartu bergambar yang telah mereka urutkan di depan kelas.

Guru menampilkan gambar-gambar dalam rangkaian cerita melalui tampilan flip flash album deluxe, kemudian bertanya pada siswa apakah kartu bergambar yang mereka urutkan sudah sesuai, memberitahu siswa untuk membuat boneka kertas tokoh yang terdapat dalam cerita "Hansel \& Gretel", membimbing siswa berdiskusi dalam kelompok untuk menentukan pembagian peran dalam cerita, membagikan lembaran prototype 4 tokoh cerita pada masing-masing kelompok, mendampingi siswa memotong, melipat dan merangkai lembaran prototype menjadi bentuk 3 dimensi (boneka kertas) sesuai dengan pembagian perannya, memberikan reward pada kelompok siswa yang telah menyelesaikan boneka kertasnya.

Guru tidak memberikan motivasi pada siswa yang belum menyelesaikan tugasnya, serta tidak membimbing dan mendampingi siswa yang belum selesai merangkai boneka kertas hingga selesai. Guru meminta siswa menunjukkan boneka kertas yang telah mereka rangkai serta memberi contoh bermain peran. Guru meminta siswa berbagi peran kemudian memainkan peran dalam cerita "Hansel \& Gretel". Guru membagikan lembar penilaian dan meminta siswa untuk mulai menuliskan kembali cerita anak "Hansel \& Gretel" menggunakan kata-kata sendiri secara individu

\section{- Pengamatan Aktivitas Siswa}

Pengamatan dilaksanakan pada saat kegiatan pembelajaran di ruang kelas, pengamatan ini dilakukan untuk mengetahui aktivitas siswa dalam mengikuti pembelajaran menuliskan kembali cerita anak dengan metode storytivty. Berdasarkan hasil pengamatan yang dilakukan peneliti mendapatkan data bahwa siswa aktif berperan dalam pembelajaran, artinya guru tidak mendominasi pelajaran, siswa aktif dalam kegiatan kelompok dan berdiskusi, siswa tampak senang ketika menyelesaikan tugas mengurutkan kartu bergambar, beberapa siswa 
masih belum aktif untuk mengajukan dan menjawab pertanyaan dari guru, juru bicara dalam kelompok siswa masih kurang percaya diri dalam menceritakan kembali kisah "Hansel \& Gretel", siswa merasa kesulitan dan putus asa dalam merangkai boneka kertas, bahkan terdapat siswa yang tidak menyelesaikan boneka kertasnya. Siswa putra merasa kurang percaya diri dalam memainkan peran, beberapa kelompok tidak melakukan permainan peran karena masih menyelesaikan boneka kertas.

Berdasarkan hasil observasi tersebut guru dan mitra pendidik melakukan analisis terhadap hasil tulisan siswa. Adapun hasil analisis tersebut menunjukkan: rata-rata jumlah kata seluruh siswa kelas II-B dalam menuliskan kembali cerita anak setelah siklus I adalah 74 kata, terdapat peningkatan kemampuan siswa dalam menuliskan kembali cerita anak, namun masih terdapat 50\% siswa yang belum mencapai KKM dalam menulis cerita. Hal ini menunjukkan siswa masih kesulitan menggali ide, kata-kata dan kalimat yang tepat untuk menulis.

Guru belum melaksanakan RPP yang telah direncanakan secara maksimal, ada beberapa tindakan yang seharusnya dilakukan, akan tetapi tidak dilakukan, seperti: guru tidak membentuk kelompok baru untuk siswa beranggotakan 4 anak akan tetapi menggunakan kelompok berdasarkan tempat duduk siswa, guru tidak mempersilahkan siswa untuk bertanya tentang cerita yang telah dibacakan, guru tidak memberikan motivasi pada siswa yang belum menyelesaikan tugasnya, guru tidak memberi contoh bermain peran, guru tidak memberikan simpulan materi yang diajarkan. Oleh karena itu, hasil penelitian ini belum maksimal, guru berencana untuk melanjutkan tindakan pada siklus selanjutnya yaitu siklus II yang merupakan perbaikan dari siklus I.

\section{Siklus II}

Proses pembelajaran menuliskan kembali cerita anak yang telah dilaksanakan pada siklus I sudah baik, tetapi belum maksimal. Hasil tulisan siswa masih terdapat kekurangan sehingga memerlukan perbaikan.

Untuk mengatasi kekurangan dan kelemahan pada siklus I, maka guru merencanakan tindakan untuk siklus II.

\section{a. Hasil Belajar}

Sebagaimana yang telah direncanakan, tindakan pada siklus II dilaksanakan dalam tiga pertemuan. Adapun hasil belajar siswa dalam menuliskan kembali cerita anak setelah dillakukan siklus II adalah sebagai berikut: rata-rata jumlah kata seluruh siswa kelas II dalam menuliskan kembali cerita anak setelah siklus I adalah 92 kata, beberapa siswa masih kesulitan mencari kata-kata dan kalimat yang tepat untuk menulis, jumlah kata terendah yang dihasilkan siswa adalah 49 kata, sedangkan jumlah kata tertinggi yang dihasilkan siswa adalah 127 kata, terdapat peningkatan kemampuan siswa dalam menuliskan kembali cerita anak, masih terdapat $10 \%$ siswa yang belum mencapai KKM dalam menulis cerita

\section{b. Pengamatan (Observasi) \\ - Pelaksanaan tindakan guru}

Tindakan siklus II dilaksanakan sesuai dengan menjalankan RPP yang telah disusun dalam tiga pertemuan (6x30 menit). Guru membuka pelajaran, memberikan apersepsi mengenai pengalaman siswa dibacakan cerita oleh orang tua, cerita yang pernah mereka dengar, apakah mereka menyukai cerita tersebut, membentuk kelompok baru untuk siswa beranggotakan 4 anak, mengkondisikan siswa untuk tenang dan diam saat akan dimulai pembacaan cerita, membacakan teks cerita "Hansel \& Gretel" dengan cara yang interaktif, mempersilahkan siswa untuk bertanya tentang cerita yang telah dibacakan, membagikan beberapa kartu bergambar pada masing-masing kelompok, 
memberi instruksi yang jelas kepada siswa tentang kegiatan mengurutkan kartu bergambar, membimbing siswa dalam kelompok untuk mengurutkan kartu bergambar dengan cara memberikan nomor urut pada kotak yang telah disediakan di pojok kiri atas kartu bergambar, memberikan penguatan pada semua kelompok yang berhasil mengurutkan kartu bergambar, meminta siswa berdiskusi menentukan juru bicara untuk masing-masimg kelompok, memberikan contoh bagaimana cara menceritakan kisah "Hansel \& Gretel" secara lisan di depan kelas menggunakaan kartu bergambar, meminta siswa menceritakan secara lisan cerita "Hansel \& Gretel" berdasarkan kartu bergambar yang telah mereka urutkan di depan kelas, menampilkan gambargambar dalam rangkaian cerita melalui tampilan flip flash album deluxe, kemudian bertanya pada siswa apakah kartu bergambar yang mereka urutkan sudah sesuai, memberitahu siswa untuk membuat boneka kertas tokoh yang terdapat dalam cerita "Hansel \& Gretel", membimbing siswa berdiskusi dalam kelompok untuk menentukan pembagian peran dalam cerita, membagikan lembaran prototype 4 tokoh cerita pada masing-masing kelompok, mendampingi siswa memotong, melipat dan merangkai lembaran prototype menjadi bentuk 3 dimensi (boneka kertas) sesuai dengan pembagian perannya, memberikan reward pada kelompok siswa yang telah menyelesaikan boneka kertasn, ya, memberikan motivasi pada siswa yang belum menyelesaikan tugasnya, membimbing dan mendampingi siswa yang belum selesai merangkai boneka kertas hingga selesai, meminta siswa menunjukkan boneka kertas yang telah mereka rangkai, memberi contoh bermain peran, meminta siswa berbagi peran kemudian memainkan peran dalam cerita "Hansel \& Gretel", dan membagikan lembar penilaian dan meminta siswa untuk mulai menuliskan kembali cerita anak "Hansel \& Gretel" menggunakan kata-kata sendiri secara individu.

\section{- Pengamatan Aktivitas Siswa}

Pengamatan dilaksanakan pada saat kegiatan pembelajaran di ruang kelas, pengamatan ini dilakukan untuk mengetahui aktivitas siswa dalam mengikuti pembelajaran menuliskan kembali cerita anak dengan metode storytivty. Berdasarkan hasil pengamatan yang dilakukan peneliti, diperoleh hasil sebagai berikut: siswa aktif dalam kegiatan kelompok dan berdiskusi, siswa tampak senang ketika menyelesaikan tugas mengurutkan kartu bergambar dan bermain peran, siswa aktif untuk mengajukan dan menjawab pertanyaan dari guru, juru bicara dalam kelompok siswa lebih percaya diri dalam menceritakan kembali kisah "Pinokio", siswa dapat menyelesaikan boneka kertas dengan baik, siswa yang kesulitan dalam merangkai boneka kertas dibimbing secara optimal oleh guru, hingga seluruh siswa dapat menyelesaikan boneka kertasnya, guru mendampingi siswa yang kurang percaya diri dalam memainkan peran, seluruh kelompok melakukan permainan peran, bagi kelompok yang masih kesulitan dibimbing oleh guru

\section{c. Analisis dan Refleksi}

Berdasarkan hasil observasi tersebut guru dan mitra pendidik melakukan analisis terhadap hasil tulisan siswa. Adapun hasil analisis tersebut menunjukkan: rata-rata jumlah kata seluruh siswa kelas II-B dalam menuliskan kembali cerita anak setelah siklus II adalah 92 kata. Terdapat 10\% siswa yang belum mencapai KKM sedangkan $90 \%$ siswa telah mencapai $\mathrm{kkm}$ dalam menuliskan kembali cerita anak menggunakan kata-kata sendiri. Guru telah melaksanakan RPP yang telah direncanakan secara maksimal. Hasil yang diperoleh ini sudah sesuai dengan indikator keberhasilan yang hendak dicapai maka siklus berhenti. 


\section{PEMBAHASAN}

Penelitian ini dilakukan setelah guru mengalami hambatan ketika mengajar kompetensi dasar: menceritakan kembali cerita anak yang didengarkan menggunakan kata-kata sendiri. Dalam pembelajaran tersebut menunjukkan kualitas proses dan hasil pembelajaran yang rendah. Peneliti selaku guru tematik kelas II berkolaborasi dengan pendidik mitra untuk mengatasi masalah tersebut dengan memanfaatkan metode storytivity dalam proses pembelajaran menuliskan kembali cerita anak.

Pemilihan metode tersebut dengan pertimbangan sebagai berikut, metode storytivity merupakan metode yang mengembangkan imajinasi dan kreativitas anak, dengan harapan siswa tidak merasa kesulitan dan lebih kreatif dalam menuliskan kembali cerita anak menggunakan kata-kata sendiri dan siswa lebih bebas untuk mengembangkan kemampuan berbahasanya.

Guru dan pendidik mitra kemudian menyusun rencana untuk siklus I. Siklus I ini mendeskripsikan pembelajaran menuliskan kembali cerita anak dengan metode storytivity. Ternyata masih terdapat kelemahan atau kekurangan dalam pelaksanaannya. Siklus II dilaksanakan untuk mengatasi kelemahan atau kekurangan yang ada pada siklus I. Berdasarkan tindakan-tindakan tersebut, guru dikatakan telah berhasil melaksanakan pembelajaran menuliskan kembali cerita anak dengan metode storytivity yang mampu membantu siswa dalam memunculkan ide dan mengembangkannya sehingga kemampuan menuliskan kembali cerita anak dapat berkembang dengan optimal.

Keberhasilan metode ini dalam meningkatkan kualitas proses dan hasil pembelajaran menuliskan kembali cerita anak dapat dilihat dari indikator-indikator sebagai berikut:

\section{Kualitas proses pembelajaran menuliskan kembali cerita anak meningkat.}

Tindakan-tindakan berupa penerapan metode storytivity yang dilaksanakan tiap siklus mampu meningkatkan kualitas proses pembelajaran menuliskan kembali cerita anak siswa kelas II-B SD Al Muttaqien Surabaya. Peningkatan dari segi proses pembelajaran dapat dilihat pada beberapa indikator berikut.

a. Meningkatnya keaktifan siswa

Keaktifan siswa dalam pembelajaran menulis deskripsi mengalami peningkatan dari siklus ke siklus. Indikator keaktifan siswa dalam proses pembelajaran meliputi keaktifan siswa dalam kegiatan kelompok dan berdiskusi, bertanya dan menjawab pertanyaan guru, dan mengerjakan tugas-tugas yang diberikan guru dengan senang.

b. Meningkatnya motivasi siswa

Setelah adanya tindakan memanfaatkan metode storytivity motivasi siswa dalam pembelajaran menuliskan kembali cerita anak meningkat. Ketika diminta untuk menyelesaikan tugasnya siswa tampak senang, yaitu mulai dari aktivitas mengurutkan kartu bergambar, menyaksikan tampilan flip flash album deluxe, merangkai boneka kertas, bermain peran, hingga menuliskan kembali cerita anak.

c. Meningkatnya percaya diri siswa

Setelah tindakan dilaksanakan, percaya diri siswa meningkat. Ketika diminta untuk menceritakan ulang secara lisan di depan kelas dan bermain peran tampak percaya diri.

d. Meningkatnya keterampilan guru dalam mengelola kelas

Kemampuan guru dalam mengelola kelas merupakan salah satu penentu keberhasilan dalam suatu proses pembelajaran. Setelah tindakan dilaksanakan, kemampuan guru dalam mengelola kelas semakin meningkat. Guru membangkitkan keaktivan siswa dengan menggunakan system kompetisi antar kelompok, membangkitkan motivasi siswa dengan cara memberikan reward bagi siswa yang mengerjakan tugasnya dengan baik. Berikut ini adalah perbandingan pelaksanaan tindakan guru dalam siklus I dan siklus II:

\section{Kualitas hasil pembelajaran menuliskan kembali cerita anak meningkat.}

Setelah dilakukan tindakan dengan menerapkan metode storytivity kemampuan siswa menuliskan kembali cerita anak meningkat, hal tersebut dapat terlihat dari: rata-rata jumlah kata seluruh siswa kelas II-B dalam menuliskan kembali cerita anak setelah siklus II adalah 
92 kata. Terdapat 10\% siswa yang belum mencapai KKM sedangkan 90\% siswa telah mencapai KKM dalam menuliskan kembali cerita anak menggunakan kata-kata sendiri.

Berdasarkan analisis data ternyata penggunaan metode storytivity dapat meningkatkan kemampuan menuliskan kembali cerita anak pada siswa kelas II-B SD Al Mutatqien Surabaya. Hal ini berarti bahwa hipotesis penelitian dapat diterima.

\section{PENUTUP}

Hasil penelitian ini dapat disimpulkan bahwa: penerapan metode storytivity dapat meningkatkan pembelajaran menuliskan kembali cerita anak. Hal ini ditandai dengan meningkatnya keaktifan, motivasi, dan percaya diri siswa dalam pembelajaran menuliskan kembali cerita anak yang mengalami peningkatan pada setiap siklusnya.

Penerapan metode storytivity dapat meningkatkan kemampuan menuliskan kembali cerita anak bagi siswa kelas II-B SD Al Muttaqien Surabaya, terdapat 90\% siswa telah mampu menuliskan kembali cerita anak menggunakan bahasanya sendiri.

\section{DAFTAR PUSTAKA}

Arikunto, Suharsimi.(2007).Manajemen Penelitian.Jakarta:Rineka Cipta.

Arikunto, S., Suhardjono, Supadi.(2012).Penelitian Tindakan Kelas.Jakarta:Bumi Aksara.

Dewiyana, Ana.(2009).Cerita Binatang Berima Dua Bahasa.Bandung:Pelangi Mizan.

Nurgiyantoro, Burhan.(2001).Penilaian Dalam Pembelajaran Bahasa dan Sastra. Yogyakarta:BPFE.

Tim Kreatif Kids Land.(2009).Storytivity: Hansel \& Gretel.Jakarta:PT. Elex Media Komputindo.

Tim Kreatif Kids Land.(2009).Storytivity: Pinokio.Jakarta:PT. Elex Media Komputindo. Wijaya, Surendra.(2009).Storytivity Hansel \& Gretel. Jakarta:PT. Elex Media Komputindo. 